\section{Access to public spaces and physical activity for Mexican adult women}

\author{
Acceso a espacios públicos y actividad física en \\ mujeres adultas mexicanas
}

O acesso aos espaços públicos e a atividade
física em mulheres adultas mexicanas
Ietza Bojorquez 1

Lina Ojeda-Revah 1

Rolando Diaz 2

doi: 10.1590/0102-311X00065217

\begin{abstract}
The aim of this article was to explore the association between access to public spaces and physical activity for adult women, controlling and testing interactions with sociodemographic and public spaces characteristics. We combined sociodemographic data from a survey with the adult (18-65 years of age) women population of Tijuana, Mexico, conducted in $2014(N=2,345)$; with data from a 2013 study on public spaces in the same city. We evaluated access to public spaces by the presence and total area of public spaces in buffers of 400,800, 1,000 and 1,600m around the participants' homes. We measured physical activity with the short version of the International Physical Activity Questionnaire (IPAQ-short). We employed multinomial logistic models to evaluate the association between access to public spaces and physical activity, and tested for interactions between access to public spaces and public spaces quality and sociodemographic characteristics. We observed no interaction between access to public spaces and public spaces quality in their effect on physical activity. There was an association between the presence of public spaces in the $400 \mathrm{~m}$ buffer, and higher odds of being in the low physical activity level (as opposed to being in the moderate level) (coefficient: 0.50; 95\%CI: 0.13; 0.87). Participants who used public transport were less likely to be in the low physical activity level (coefficient: -0.57; 95\%CI: -0.97; -0.17). We suggest that, in this population, the access to public spaces might be less relevant for physical activity than other elements of the urban environment and sociodemographic characteristics.
\end{abstract}

Physical Activity; Green Areas; Women's Health

\author{
Correspondence \\ I. Bojorquez \\ El Colegio de la Frontera Norte. \\ Km 18.5 Carretera Escenica Tijuana-Ensenada, Tijuana, Baja \\ California 22560, México. \\ ietzabojorquez@gmail.com \\ 1 El Colegio de la Frontera Norte, Tijuana, México. \\ 2 El Colegio de Sonora, Hermosillo, México.
}




\section{Introduction}

Physical activity is a central component of chronic disease prevention. According to the World Health Organization (WHO), the lack of physical activity is the fourth risk factor for disease worldwide, and $6 \%$ of all deaths could be avoided if all the population met the recommended physical activity levels 1. On the other hand, the increase in sedentary occupations and decrease in active transport in modern urban environments have caused physical activity levels to fall, and, according to recent estimations, physical inactivity affects $31.1 \%$ of the world's adult population 2 .

The urban environment is one of the factors that can either promote or reduce physical activity. Public spaces, such as parks and green areas, sports fields, and other open spaces, are free access places where people can engage in physical activity. They can also be attractive destinations, stimulating people to go for a walk, and, as they improve urban aesthetics, public spaces can stimulate walks around or through them during everyday activities, thus promoting active transport. Because of the this, it has been suggested that the presence of public spaces in urban areas can contribute to physical activity promotion and chronic disease prevention 3,4 .

Even while the relationship between access to public spaces and physical activity is intuitively reasonable, research has found contrasting results in this regard. A review of studies published up to 2005 reported that only $40 \%$ of them had found a positive association between public spaces and physical activity, while a similar percentage showed mixed results, and the rest failed to find an association 5 . A later review also found a mixture of positive and null findings 6 , and more recent research reports both positive associations between public spaces and physical activity 7 and absence of association 8 . To complicate the picture, some authors have found negative associations: people living close to public spaces with lower physical activity levels than those who live further away 9,10 .

This divergence in results can be partially explained by the use of diverse study designs and definitions of access to public spaces, and also because the kinds of physical activity evaluated differ 4,6. Because of this, some authors have recommended the use of multiple indicators of access including distance to public spaces and total public spaces area in the vicinity ${ }^{11}$. As the distance between home and public spaces might influence the likelihood of visiting, it is also important to assess the effect of different buffers. A distance of $400 \mathrm{~m}$ is considered a reasonable, walkable distance for most potential users 12,13 , and thus the association between public spaces and physical activity might be stronger at this distance, but other distances are also employed in the literature 11.

It has also been suggested that some characteristics of public spaces, and of their potential users, could explain the disparate findings. As for the former, a better quality of public spaces (indicated by attractiveness, safety, number and kind of services provided, or size) could increase their use 4 . In this regard, qualitative studies have reported that suboptimal conditions of public spaces are important perceived barriers to use 14,15 , and at least one previous study showed that having access to more attractive and bigger public spaces increased the likelihood of taking a walk 16.

On the other hand, the association between access to public spaces and physical activity could be different according to sociodemographic characteristics, such as sex, age or socioeconomic level $4,11,17,18,19$. The possibility of interaction between sociodemographic characteristics and access to public spaces has been justified in two ways. First, the effect of having a public space close by might be stronger for those who spend more time at home, such as older adults 17 . Second, public spaces could make a greater difference for those with more barriers to physical activity, such as persons of lower socioeconomic level 20. Following both lines of argument, the effect of access to public spaces should be stronger on older persons, homemakers and those of lower socioeconomic level. The association of public spaces and physical activity, and the modification of this association by other variables, is an important subject, and since most research has been conducted in upper-income countries, it is important to explore it in other contexts 4.

As worldwide physical inactivity is more prevalent among women 2,21, it is important to explore the correlates of physical activity in females. As physical activity decreases with age, exploring the association of elements of the urban environment with physical activity among adult women could help develop preventive policies specific to this at-risk group. The aim of this article is to explore the association between access to public spaces and physical activity in adult women. Our guiding hypotheses were that in a representative sample of women living in an urban area: (1) there would 
be a positive association between access to public spaces and physical activity; (2) the association would be more marked with increased quality of public spaces; and (3) there would be interactions between access to public spaces and sociodemographic characteristics (age, occupation, children, socioeconomic level and education), with access to public spaces having a more marked association with physical activity in older women, homemakers, those with young children, and those of lower socioeconomic level and education. Based on the literature above, our rationale for the interaction hypotheses was that for younger, workingwomen or students, those without children or with older children, and those of higher socioeconomic level and education, physical activity could be implemented even in the absence of public spaces, since they would have access to other facilities, such as gyms or private exercise groups, and they would also have more time to devote to exercise.

\section{Materials and methods}

\section{Site, sample and data sources}

The study was conducted in Tijuana, Mexico, a city of over 1.5 million inhabitants 22 at the MexicoUnited States border. As many other Latin-American cities, Tijuana experienced rapid and chaotic urban growth starting in the 1980's, with the emergence of numerous unplanned, irregular settlements 23 . In the 21 st century, governmental incentives for the construction of suburban developments added to this pattern. The new suburban houses were mainly sold to lower-middle income families, and established in non-urbanized areas with limited services and low connectivity with the rest of the city 24 . Although current legislation requires green areas in all new housing developments 25 , their size tends to be small and most of them are neglected as soon as the developing companies complete house selling 26 .

Data for the analysis came from two sources: a household survey in 2014, and a study on the distribution and quality of public spaces in the city in 2013, both conducted by the authors.

The objective of the household survey was to explore health-related practices and their social correlates among women in Tijuana. A target sample size of 2,500 was calculated based on the minimum prevalence of interest, and a probability, multi-stage, stratified sampling design was employed. The primary sampling units (PSUs) were the Basic Geo-Statistic Areas defined by Mexico's National Institute of Statistics and Geography (INEGI), stratified by level of social marginalization (as defined by INEGI). From each selected PSU five blocks were selected at random, all houses in each block were visited, and one eligible participant was selected from each household. The selection criteria for participants were: (1) female; (2) between 18 and 65 years of age; and (3) agreeing to participate after an informed consent procedure. A total of 2,345 participants undertook the survey, for a response rate of $94 \%$.

The 2013 study of public spaces aimed to assess the distribution and quality of all public spaces in Tijuana from an environmental justice perspective. The concept of public spaces is complex, including dimensions, such as open access, green coverage, etc. ${ }^{27}$. For the purposes of the study, the definition of public spaces was taken from Mexico's Development Ministry 28 which includes "...community spaces that... promote communication, interrelation and social integration, as well as interrelation with nature", and can include parks and playgrounds of different sizes and characteristics. Operatively, public spaces were defined as all such spaces listed in the municipality's register of public spaces, and all of them were visited by the same researcher. The researcher completed an inventory of services for each public space (e.g., playground equipment, courts or sports fields, walking paths, benches, etc.). Each service in the list was scored as 1 (present) or 0 (absent), and the values were added to create a single score of quality. The values of the score observed ranged from 0 to 9 .

\section{Instruments and variables}

We assessed the dependent variable (physical activity) with the International Physical Activity Questionnaire (IPAQ) 29 in its short Spanish version, available from the web page of the authors' questionnaire (https://sites.google.com/site/theipaq/home). The IPAQ-short asks the number of days/week and 
the number of minutes/day that the respondent engaged in moderate-intensity physical activity, vigorous-intensity physical activity, walking and sitting during the past seven days. We followed the data cleaning protocol and scoring algorithm established by the IPAQ group ${ }^{30}$. The algorithms result in a value of physical activity in metabolic equivalent minutes per week (MET-minutes/week), and also classify participants in three levels of physical activity (low, moderate, high). The three categories of physical activity are recommended by the IPAQ group as relevant for public health purposes, with the moderate category considered sufficient to prevent diseases, while the high category could be associated with further improvements in health. In this study, we employ the three-category variable as dependent variable 30 .

We evaluated the main independent variable (access to public spaces) through the geographic information systems (GIS). We located the blocks where the participants in the survey lived, and established buffers of 400, 800,1,000 and 1,600m around the center of each block. We selected these buffers for comparability, as they are the most frequently employed in other studies 11 . Using cartographic data from the public spaces study, we evaluated the access to public spaces in each buffer as the presence of at least one public space in the buffer (dichotomous variable). We also computed a variable of total public space area $\left(\mathrm{m}^{2}\right)$ in the buffer (continuous variable).

As indicator of public spaces quality, we employed the sum of services according to the 2013 inventory. The rank of values for this variable was 0-9, and services included bathrooms, lighting, kiosks, benches and playground, among others. We assigned to the survey participants the value of the highest-scoring public space for each buffer around the block they lived in. Thus, for example, if there were three public spaces in the $400 \mathrm{~m}$ buffer around the block a participant lived in, she would be assigned a value of 1 in the dichotomous variable "presence of public spaces in $400 \mathrm{~m}$ buffer", a value of "total public spaces area in $400 \mathrm{~m}$ buffer" corresponding to the area in $\mathrm{m}^{2}$ of all three public spaces, and a value of "quality of public spaces in $400 \mathrm{~m}$ buffer" corresponding to the highest scoring public space among the three. All public spaces-related variables were extracted and computed using the ArcGIS (http://www.esri.com/software/arcgis/index.html) spatial analysis software.

We included covariates expected to be associated with both access to public spaces and physical activity, and those that according to our hypotheses could modify the association between public spaces and physical activity. These covariates included age, body mass index (BMI, calculated from weight and height measured by interviewers as $\mathrm{kg} / \mathrm{m}^{2}$ ), having a diagnosis of either diabetes mellitus or hypertension, occupation (categories "working", "student", "homemaker" - the latter including also those who were retired or did not work nor study), children (categories "no children", "at least one children $\leq 5$ years of age", "all children $>5$ years of age"), marital status ("single", "married/cohabiting", and "separated/widowed"), socioeconomic level (index computed from principal component analysis of questions about household goods and services), education (with categories "elementary school - 0 to 6 years", "junior high -7 to 9 years", "high school - 10 to 12 years" and "more than high school $12+$ years"), and most frequently used transport ("private car", "public transport", and "walk or bike"). Following our hypotheses, we tested interactions of access to public spaces with age, children, occupation, socioeconomic level and education.

\section{Analysis}

After exploratory analysis of the distribution of all variables of interest, we evaluated the association between access to public spaces and physical activity level through multinomial regression models, appropriate for categorical dependent variables. In the models, we employed as reference category the moderate physical activity level, and tested for change in the log-odds of being in either the low or high categories (vs. being in the moderate category) associated with change in the independent variables. In the first set of models, we conducted bivariate analysis with the variables presence of public spaces and total public spaces area separately as independent variables, evaluating their association with physical activity at each buffer. Then to assess the interaction between public spaces quality and public spaces presence or area, we restricted analyses to participants with presence of public spaces in the buffer, and evaluated the association between public spaces quality and physical activity. As these analyses failed to show an association between public spaces quality and physical activity, we dropped the public spaces quality variable from further analyses. The next step was to conduct multivariate 
analyses including covariates, and exploring interactions by means of multiplicative terms in the regressions. Interactions with $\mathrm{p}<0.05$ were kept in the final models.

Sampling weights for each participant were calculated as the inverse of the probability of selection, and adjusted by non-response. We considered the sample design in all analyses, employing the svy module in Stata (StataCorp LP, College Station, USA) to adjust standard errors and consider weights.

\section{Compliance with ethical principles}

All procedures of the survey were reviewed and approved by the Ethics Committee of the El Colegio de la Frontera Norte, and were in compliance with ethical principles as stated in the Declaration of Helsinki.

\section{Results}

Table 1 shows the characteristics of the population, as estimated from the study sample. The table also shows the distribution of covariates by access to public spaces in the $400 \mathrm{~m}$ buffer. Participants who lived near a public spaces were marginally more likely to be in the low physical activity level, and less likely to have only children over 5 years of age and to have only elementary education. The distribution of other covariates was similar regardless of access to public spaces, and comparisons employing other buffers showed similar results (data not shown). According to IPAQ criteria, 23.3\% of respondents were in the low physical activity level, $41.7 \%$ were in the moderate level, and 35\% were in the high level. The mean of MET-minutes/week was 2,460, with most of it coming from moderateintensity physical activity (data not shown).

Table 2 shows the estimated distribution of access to public spaces. About one fifth of the population had a public space in the $400 \mathrm{~m}$ buffer around their block, and the percentage with a public space was higher for wider buffers. Still, about $14 \%$ of the population had no access to public spaces in the buffers considered.

In Table 3, we show the results of the multivariate multinomial regression for the association between access to public spaces and physical activity level. The reference category in the model was moderate physical activity, so that the adjusted coefficient for the presence of a public space in the $400 \mathrm{~m}$ buffer $(0.50 ; 95 \% \mathrm{CI}: 0.13 ; 0.87)$ means that having a public space close to home was directly associated with being in the low (vs. moderate) physical activity category. The coefficient comparing the odds of being in the high (vs. moderate) physical activity category was not statistically significant (0.07; 95\%CI: -0.40; 0.54). Likewise, in a different model using as indicator of access the total public spaces area, a larger area in the $400 \mathrm{~m}$ buffer was associated with higher odds of being in the low physical activity category (data not shown). Analyses with other buffers did not show evidence of an association between access to public spaces and physical activity (data not shown). The interactions explored were not statistically significant, and therefore were not kept on the model (Table 4).

As for the covariates (Table 3), age had an inverted-U association with physical activity, so that the odds of being in the low physical activity level first decreased and then increased with age, and the opposite happened with the odds of being in the high physical activity level. A higher BMI was positively associated with being in the low physical activity level, and using public transport was inversely associated with being in the low physical activity level.

\section{Discussion and conclusions}

According to our results, $20.6 \%$ of the female population in Tijuana lived within $400 \mathrm{~m}$ of a public spaces, and $86.1 \%$ lived within $1,600 \mathrm{~m}$ of one. While data are not strictly comparable, this is consistent with a study in another city in the north of Mexico (Hermosillo, Sonora) reporting that 70.3\% of the city's neighbourhoods had a public spaces within their limits 14 . While these figures could seem high, current recommendations such as those of the European Environment Agency establish that people should live no more than 15 walking minutes away from a green area, and others even suggest a 


\section{Table 1}

Participants' characteristics, total and by access to public space, among women in Tijuana, Mexico, 2014 *.

\begin{tabular}{|c|c|c|c|}
\hline & $\begin{array}{c}\text { No public space in } 400 \mathrm{~m} \\
\% \text { or mean }(95 \% \mathrm{Cl})\end{array}$ & $\begin{array}{l}\text { Public space in } 400 \mathrm{~m} \\
\% \text { or mean }(95 \% \mathrm{Cl})\end{array}$ & $\begin{array}{c}\text { Total } \\
\% \text { or mean }(95 \% \mathrm{Cl})\end{array}$ \\
\hline \multicolumn{4}{|l|}{ Physical activity level (\%) } \\
\hline Low & $21.8(19.3 ; 24.6)$ & $29.1(24.2 ; 34.5)$ & $23.3(21.0 ; 25.8)$ \\
\hline Moderate & $43.1(40.6 ; 45.6)$ & $36.3(30.4 ; 42.7)$ & $41.7(39.3 ; 44.1)$ \\
\hline High & $35.1(32.0 ; 38.4)$ & $34.6(28.2 ; 41.7)$ & $35.0(32.0 ; 38.1)$ \\
\hline Age (mean) & $37.0(36.5 ; 37.5)$ & $36.9(35.7 ; 38.2)$ & $37.0(36.5 ; 37.4)$ \\
\hline Body mass index (mean) ** & $28.4(28.1 ; 28.8)$ & $28.0(27.5 ; 28.5)$ & $28.4(28.1 ; 28.7)$ \\
\hline Chronic disease & $25.7(23.5 ; 28.0)$ & $23.2(17.8 ; 29.6)$ & $25.1(22.9 ; 27.5)$ \\
\hline \multicolumn{4}{|l|}{ Occupation (\%) } \\
\hline Working & $43.1(41.3 ; 45.0)$ & $42.4(39.2 ; 45.7)$ & $43.0(41.5 ; 44.4)$ \\
\hline Student & $7.2(6.0 ; 8.5)$ & $6.7(4.8 ; 8.9)$ & $7.0(6.1 ; 8.1)$ \\
\hline Homemaker & $49.8(48.6 ; 50.9)$ & $51.0(48.6 ; 53.5)$ & $50.0(49.3 ; 50.8)$ \\
\hline \multicolumn{4}{|l|}{ Children (\%) } \\
\hline No children & $20.4(18.0 ; 23.0)$ & $25.0(21.3 ; 29.1)$ & $21.3(19.0 ; 23.9)$ \\
\hline Children $\leq 5$ year old & $31.1(28.4 ; 33.9)$ & $31.6(26.4 ; 37.2)$ & $31.2(28.9 ; 33.5)$ \\
\hline Only children $>5$ years old & $48.6(46.7 ; 50.4)$ & $43.4(40.0 ; 47.4)$ & $47.5(45.8 ; 49.2)$ \\
\hline \multicolumn{4}{|l|}{ Marital status } \\
\hline Single & $22.2(20.8 ; 23.8)$ & $24.1(19.5 ; 29.4)$ & $22.6(19.5 ; 29.4)$ \\
\hline Married/Cohabiting & $67.5(65.2 ; 69.6)$ & $63.7(59.1 ; 68.0)$ & $66.7(64.7 ; 68.6)$ \\
\hline Separated/Widowed & $10.3(8.9 ; 11.9)$ & $12.3(9.2 ; 16.2)$ & $10.7(9.5 ; 12.1)$ \\
\hline Socioeconomic level (mean) & $0.00(-0.17 ; 0.17)$ & $0.40(-0.08 ; 0.88)$ & $0.08(-0.10 ; 0.28)$ \\
\hline \multicolumn{4}{|l|}{ Education (\%) } \\
\hline Elementary (0-6 years) & $27.1(24.7 ; 29.7)$ & $19.5(14.4 ; 25.7)$ & $25.6(23.4 ; 28.0)$ \\
\hline Junior high (7-9 years) & $33.4(30.5 ; 36.4)$ & $27.0(19.5 ; 36.0)$ & $32.1(28.9 ; 35.4)$ \\
\hline High school (10-12 years) & $27.9(25.5 ; 30.6)$ & $32.3(27.3 ; 37.6)$ & $28.8(26.3 ; 31.5)$ \\
\hline More than high school (12+ years) & $11.5(9.3 ; 14.2)$ & $22.3(11.8 ; 35.3)$ & $13.5(10.5 ; 17.3)$ \\
\hline \multicolumn{4}{|l|}{ Most frequent transport } \\
\hline Private car & $38.8(34.8 ; 42.9)$ & $48.2(34.2 ; 62.4)$ & $40.7(36.0 ; 45.7)$ \\
\hline Public transport & $55.7(51.4 ; 60.0)$ & $47.8(34.5 ; 61.6)$ & $54.1(49.1 ; 58.9)$ \\
\hline Walk or bike & $5.5(4.3 ; 7.0)$ & $4.0(2.3 ; 7.1)$ & $5.2(4.1 ; 6.6)$ \\
\hline
\end{tabular}

95\% Cl: 95\% confidence interval.

* Estimated means and proportions considering sample design. Unweighted $n=2,345$ (may differ for some variables because of missing data);

** Body mass index calculated only for non-pregnant participants.

maximum distance of $300 \mathrm{~m}$ between home and public spaces 31 . Put in this context, our results show a relative lack of access.

In contrast to previous studies 7, in our analysis we found no evidence of the expected positive association between access to public spaces and physical activity. Instead, we observed a negative association, with the presence of public spaces in the $400 \mathrm{~m}$ buffer increasing the odds of being in the low physical activity category. Other authors have reported similar results. In a study in Australia, King et al. 9 found that living close to a park was associated with less frequency of walking among adults, and suggested it could be due to an association between park proximity and other area characteristics, such as less connectivity or less destinations reachable on foot. A similar explanation could apply in our case; however, we lack data to control those factors. In a comparison between locations in Australia and the United States, Veitch et al. 32 found that access to public spaces was associated with physical activity only in the former. In Cuernavaca, Mexico, Salvo et al. 33 observed a negative association between public spaces proximity and physical activity. Finally, Hillsdon et al. 10 found that more access to green areas was associated with less recreational physical activity in middle aged 
Table 2

Distribution of access to public spaces and physical activity among women in Tijuana, Mexico, 2014 *.

\begin{tabular}{ll}
\hline Variable & $\%(\mathbf{9 5} \% \mathbf{C l})$ \\
\hline Presence of public spaces in the buffer & \\
$400 \mathrm{~m}$ & $20.6(13.0 ; 31.1)$ \\
$800 \mathrm{~m}$ & $52.9(39.7 ; 65.7)$ \\
$1,000 \mathrm{~m}$ & $66.9(52.7 ; 78.5)$ \\
$1,600 \mathrm{~m}$ & $86.1(73.1 ; 93.4)$ \\
\hline
\end{tabular}

95\% Cl: 95\% confidence interval.

* Estimated means and proportions considering sample design. Unweighted $n=2,345$.

and older adults, and suggested that other unmeasured factors associated with the presence of green areas could explain the result. In our case, living close to a public space could indicate a better social position, as shown in other studies of the distribution of public spaces in Mexico 14,26. Even though we controlled the socioeconomic level and education, it is possible that other aspects of social position or social environment that were not captured by those variables were associated with living in areas with more access to public spaces. Since a better social position is associated with more exercise, but at the same time with less occupational or transport-related physical activity 2 , this could result in an inverse distribution of total physical activity in relation to social position, which in turn could explain the higher odds of being in the low physical activity level of participants living close to public spaces.

Similar to other authors 10, we failed to observe supporting evidence for our second hypothesis, that the association of access to public spaces and physical activity would depend on the quality of the public spaces. In this case, it is important to consider the time lapse between the fieldwork of the public spaces study (2013) and the household survey from which data on physical activity came (2014). Some measurement error could have come from assigning to the public spaces characteristics that were no longer in place. It is also possible that public spaces characteristics that were not evaluated in this study (such as safety) were more related to their use for physical activity. Similar reasons could explain our failure to observe interactions between age, children, occupation, socieconomic level or education, and access to public spaces.

To interpret the results, it is important to consider some limitations of our study. First, the crosssectional design does not allow for the exploration of causal relations. A second main limitation is the possibility of measurement error of the main variables. While the IPAQ is widely employed for the assessment of physical activity in surveys, and it is correlated with objectively-measured physical activity, the correlations reported are weak to moderate 34 , usually overestimating the actual physical activity level 21. A related problem is that IPAQ tends to be less accurate in people with lower education level, and among those who do not routinely exercise 35. In our study, participants with lower education were less likely to have access to public spaces (Table 2). If they were more likely to overreport their physical activity, the estimated associations could be biased towards the null. A third limitation is that our measurement of access to public spaces did not consider the characteristics of the route between participants' homes and public spaces, as only Euclidian distance was considered (as opposed to street network analysis). In Tijuana, a city where streets are usually in bad conditions and there are significant slopes in some areas, the effect of these characteristics on the likelihood of visiting public spaces might be important.

An interesting finding of our study was the relationship between transportation and physical activity. As participants who employed public transport were more likely to be in the moderate physical activity level, it seems that for this population public transport could be more relevant for physical activity than access to public spaces. A systematic review of the relationship between urban environment and physical activity 6 found that walkability and mixed land use were consistently associated with more physical activity, while the presence of public spaces did not show a positive association in all studies covered. 
Table 3

Associations between access to public space and level of physical activity, among women in Tijuana, Mexico, 2014.

\begin{tabular}{|c|c|c|c|c|}
\hline & \multicolumn{2}{|c|}{ Unadjusted * } & \multicolumn{2}{|c|}{ Adjusted ** } \\
\hline & $\begin{array}{l}\text { Low vs. moderate } \\
\text { Coefficient }(95 \% \mathrm{Cl})\end{array}$ & $\begin{array}{l}\text { High vs. moderate } \\
\text { Coefficient }(95 \% \mathrm{Cl})\end{array}$ & $\begin{array}{l}\text { Low vs. moderate } \\
\text { Coefficient }(95 \% \mathrm{Cl})\end{array}$ & $\begin{array}{l}\text { High vs. moderate } \\
\text { Coefficient }(95 \% \mathrm{Cl})\end{array}$ \\
\hline Public space in $400 \mathrm{~m}$ buffer & $0.46(0.14 ; 0.78)$ & $0.16(-0.19 ; 0.51)$ & $0.50(0.13 ; 0.87)$ & $0.07(-0.40 ; 0.54)$ \\
\hline Age & $-0.12(-0.17 ;-0.07)$ & $0.00(-0.05 ; 0.05)$ & $-0.15(-0.23 ;-0.07)$ & $0.06(-0.01 ; 0.14)$ \\
\hline Age ** & $0.00(0.00 ; 0.00)$ & $-0.00(-0.00 ; 0.00)$ & $0.00(0.00 ; 0.00)$ & $-0.00(-0.00 ;-0.00)$ \\
\hline Body mass index & $0.03(0.01 ; 0.05)$ & $-0.00(-0.03 ; 0.02)$ & $0.03(0.00 ; 0.06)$ & $0.01(-0.01 ; 0.04)$ \\
\hline Chronic disease & $0.53(0.25 ; 0.81)$ & $-0.20(-0.37 ;-0.02)$ & $0.62(0.19 ; 1.04)$ & $0.09(-0.23 ; 0.42)$ \\
\hline \multicolumn{5}{|l|}{ Occupation } \\
\hline Working & Ref. & Ref. & Ref. & Ref. \\
\hline Student & $0.14(-0.33 ; 0.61)$ & $0.24(-0.21 ; 0.69)$ & $-0.56(-1.35 ; 0.24)$ & $0.14(-0.46 ; 0.75)$ \\
\hline Homemaker & $0.19(-0.04 ; 0.42)$ & $-0.07(-0.29 ; 0.16)$ & $0.20(-0.08 ; 0.47)$ & $0.03(-0.28 ; 0.34)$ \\
\hline \multicolumn{5}{|l|}{ Children (\%) } \\
\hline No children & Ref. & Ref. & Ref. & Ref. \\
\hline Children $\leq 5$ years old & $-0.30(-0.59 ;-0.00)$ & $-0.21(-0.55 ; 0.13)$ & $-0.04(-0.45 ; 0.37)$ & $-0.24(-0.74 ; 0.27)$ \\
\hline Only children $>5$ years old & $-0.18(-0.45 ; 0.09)$ & $-0.41(-0.73 ;-0.08)$ & $0.09(-0.37 ; 0.55)$ & $-0.21(-0.83 ; 0.41)$ \\
\hline \multicolumn{5}{|l|}{ Marital status } \\
\hline Single & Ref. & Ref. & Ref. & Ref. \\
\hline Married/Cohabiting & $-0.28(-0.49 ;-0.06)$ & $-0.38(-0.61 ;-0.15)$ & $-0.29(-0.71 ; 0.12)$ & $-0.28(-0.73 ; 0.16)$ \\
\hline Separated/Widowed & $-0.12(-0.52 ; 0.27)$ & $-0.52(-0.86 ;-0.18)$ & $-0.41(-0.90 ; 0.08)$ & $-0.34(-0.87 ; 0.19)$ \\
\hline Socioeconomic level & $0.03(-0.03 ; 10.0)$ & $0.02(-0.05 ; 0.08)$ & $-0.05(-0.17 ; 0.06)$ & $-0.08(-0.17 ; 0.01)$ \\
\hline \multicolumn{5}{|l|}{ Education (\%) } \\
\hline Elementary (0-6 years) & Ref. & Ref. & Ref. & Ref. \\
\hline Junior high (7-9 years) & $-0.16(-0.48 ; 0.16)$ & $0.06(-0.24 ; 0.37)$ & $0.07(-0.29 ; 0.43)$ & $-0.29(-0.61 ; 0.02)$ \\
\hline High school (10-12 years) & $0.10(-0.18 ; 0.38)$ & $0.28(0.00 ; 0.55)$ & $0.31(-0.07 ; 0.68)$ & $0.07(-0.38 ; 0.52)$ \\
\hline More than high school (12+ years) & $0.04(-0.35 ; 0.42)$ & $0.36(0.03 ; 0.68)$ & $0.13(-0.29 ; 0.56)$ & $-0.01(-0.56 ; 0.55)$ \\
\hline \multicolumn{5}{|l|}{ Most frequent transport } \\
\hline Private car & Ref. & Ref. & Ref. & Ref. \\
\hline Public transport & $-0.25(-0.50 ;-0.00)$ & $-0.26(-0.48 ;-0.05)$ & $-0.57(-0.97 ;-0.17)$ & $-0.31(-0.62 ; 0.01)$ \\
\hline Walk or bike & $-0.48(-1.09 ; 0.14)$ & $0.06(-0.46 ; 0.58)$ & $-0.55(-1.40 ; 0.31)$ & $0.22(-0.50 ; 0.95)$ \\
\hline
\end{tabular}

95\%Cl: 95\% confidence interval; Ref.: reference.

* Multinomial bivariate regression model, reference: moderate category of physical activity. Considers sample design. Unweighted $\mathrm{n}$ varies by independent variable. Pregnant participants not included in body mass index model;

** Multinomial multivariate regression model, adjusted by all variables in the table. Pregnant participants not included in the model.

Considers sample design. Unweighted $n=1,661$.

Given that our study suggests that access to public spaces was not associated with increased physical activity, and at the same time using public transport was positively associated with physical activity, the main implication in terms of public health is that promoting active transport could be an efficient way of increasing physical activity in this population. However, further studies should be conducted to explore the role of other elements of the urban environment in this relationship. From a public health perspective, an increase in the knowledge base in diverse contexts is required to improve urban environment policies to increase physical activity. 
Table 4

Interactions between access to public space in the $400 \mathrm{~m}$ buffer and sociodemographic variables *.

\begin{tabular}{|c|c|c|}
\hline Interaction between access to public space in the $400 \mathrm{~m}$ buffer and... & $\begin{array}{l}\text { Low vs. moderate } \\
\text { Coefficient }(95 \% \mathrm{CI})\end{array}$ & $\begin{array}{l}\text { High vs. moderate } \\
\text { Coefficient }(95 \% \mathrm{Cl})\end{array}$ \\
\hline Age & $0.01(-0.10 ; 0.02)$ & $0.01(-0.01 ; 0.02)$ \\
\hline \multicolumn{3}{|l|}{ Occupation } \\
\hline Student & $-0.44(-1.69 ; 0.80)$ & $-0.55(-1.58 ; 0.47)$ \\
\hline Homemaker & $-0.01(-0.47 ; 0.44)$ & $0.23(-0.40 ; 0.85)$ \\
\hline \multicolumn{3}{|l|}{ Children } \\
\hline Children $\leq 5$ years old & $-0.10(-1.00 ; 0.80)$ & $0.23(-0.78 ; 1.24)$ \\
\hline Children $>5$ years old & $-0.00(-1.00 ; 1.00)$ & $0.49(-0.47 ; 1.46)$ \\
\hline Socioeconomic level & $-0.01(-0.19 ; 0.17)$ & $0.10(-0.05 ; 0.25)$ \\
\hline \multicolumn{3}{|l|}{ Education } \\
\hline Junior high (7-9 years) & $-0.25(-1.05 ; 0.56)$ & $0.12(-0.72 ; 0.96)$ \\
\hline High school (10-12 years) & $-0.05(-0.97 ; 0.86)$ & $-0.12(-0.93 ; 0.70)$ \\
\hline More than high school (12+ years) & $0.14(-1.08 ; 1.36)$ & $-0.07(-0.98 ; 0.83)$ \\
\hline
\end{tabular}

Note: dependent variable - level of physical activity.

* Multinomial regression models, including as independent variables public space in 400m buffer, sociodemographic variable, and interaction term between public space in 400m buffer and sociodemographic variable. Only the interaction coefficients are presented (main effects not shown). Reference category for the dependent variable: moderate physical activity. All models consider sample design. Unweighted $\mathrm{n}$ varies by independent variable.

\section{Contributors}

I. Bojorquez designed the research, conceived and conducted the analysis, wrote the first draft of the manuscript and approved the final version. $\mathrm{L}$. Ojeda-Revah designed the geographical research, revised the article and approved the final version. $\mathrm{R}$. Diaz revised the geographical data analysis, revised the article and approved the final version.

\section{Acknowledgments}

The authors acknowledge the support of Rafael Vela, who prepared GIS data for analysis, and the Consejo Nacional de Ciencia y Tecnología (CONACYT) for the financial support. 


\section{References}

1. World Health Organization. Global recommendations on physical activity for health. Geneva: World Health Organization; 2010.

2. Hallal PC, Andersen LB, Bull FC, Guthold R, Haskell W, Ekelund U, et al. Global physical activity levels: surveillance progress, pitfalls, and prospects. Lancet 2012; 380:247-57.

3. Bedimo-Rung AL, Mowen AJ, Cohen DA. The significance of parks to physical activity and public health: a conceptual model. Am J Prev Med 2005; 28(2 Suppl 2):159-68.

4. Koohsari MJ, Mavoa S, Villanueva K, Sugiyama T, Badland H, Kaczynski AT, et al. Public open space, physical activity, urban design and public health: concepts, methods and research agenda. Health Place 2015; 33:75-82.

5. Kaczynski AT, Henderson KA. Environmental correlates of physical activity: a review of evidence about parks and recreation. Leisure Sciences: An Interdisciplinary Journal 2007; 29:315-54.

6. McCormack GR, Shiell A. In search of causality: a systematic review of the relationship between the built environment and physical activity among adults. Int J Behav Nutr Phys Act 2011; 8:125.

7. Sallis JF, Cerin E, Conway TL, Adams MA, Frank LD, Pratt M, et al. Physical activity in relation to urban environments in 14 cities worldwide: a cross-sectional study. Lancet 2016; 387:2207-17.

8. Koohsari MJ, Kaczynski AT, Giles-Corti B, Karakiewicz JA. Effects of access to public open spaces on walking: Is proximity enough? Landsc Urban Plan 2013; 117:92-9.

9. King TL, Thornton LE, Bentley RJ, Kavanagh AM. Does parkland influence walking? The relationship between area of parkland and walking trips in Melbourne, Australia. Int J Behav Nutr Phys Act 2012; 9:115.

10. Hillsdon M, Panter J, Foster C, Jones A. The relationship between access and quality of urban green space with population physical activity. Public Health 2006; 120:1127-32.

11. Kaczynski AT, Besenyi GM, Stanis SA, Koohsari MJ, Oestman KB, Bergstrom R, et al. Are park proximity and park features related to park use and park-based physical activity among adults? Variations by multiple socio-demographic characteristics. Int J Behav Nutr Phys Act 2014; 11:146.
12. Boone CG, Buckley GL, Grove JM, Sister C. Parks and people: an environmental justice inquiry in Baltimore, Maryland. Ann Am Assoc Geogr 2009; 99:767-87.

13. Reyes S, Figueroa IM. Distribución, superficie y accesibilidad de las áreas verdes en Santiago de Chile. EURE (Santiago) 2010; 36:89-110.

14. García-Pérez H, Lara-Valencia F. Equidad en la provisión de espacios públicos abiertos: accesibilidad, percepción y uso entre mujeres de Hermosillo, Sonora. Sociedad y Ambiente 2016; 4:28-56.

15. Carlson SA, Brooks JD, Brown DR, Buchner DM. Racial/ethnic differences in perceived access, environmental barriers to use, and use of community parks. Prev Chronic Dis 2010; 7:A49.

16. Giles-Corti B, Broomhall MH, Knuiman M, Collins $\mathrm{C}$, Douglas $\mathrm{K}, \mathrm{Ng} \mathrm{K}$, et al. Increasing walking: how important is distance to, attractiveness, and size of public open space? Am J Prev Med 2005; 28(2 Suppl 2):169-76.

17. de Vries S, Verheij RA, Groenewegen PP, Spreeuwenberg P. Natural environments-healthy environments? An exploratory analysis of the relationship between greenspace and health. Environ Plan A 2003; 35:1717-31.

18. Ruijsbroek A, Droomers M, Kruize H, van Kempen E, Gidlow CJ, Hurst G, et al. Does the health impact of exposure to neighbourhood green space differ between population groups? An explorative study in four European cities. Int J Environ Res Public Health 2017; 14:E618.

19. Maas J, Verheij RA, Groenewegen PP, de Vries S, Spreeuwenberg P. Green space, urbanity, and health: how strong is the relation? J Epidemiol Community Health 2006; 60:587-92.

20. Mitchell R, Popham F. Effect of exposure to natural environment on health inequalities: an observational population study. Lancet 2008; 372:1655-60

21. Dumith SC, Hallal PC, Reis RS, Kohl 3rd HW. Worldwide prevalence of physical inactivity and its association with human development index in 76 countries. Prev Med 2011; 53:24-8.

22. Instituto Nacional de Estadística y Geografía. Encuesta intercensal: principales resultados. Ciudad de México: Instituto Nacional de Estadística y Geografía; 2015. 
23. Sánchez-Rodríguez R. Urban and social vulnerability to climate variability in Tijuana, Mexico. In: Kasperson RE, Berberian M, editors. Integrating science and policy: vulnerability and resilience in global environmental change. New York: Routledge; 2011.p. 187-214.

24. Monkkonen P. Do Mexican cities sprawl? Housing-finance reform and changing patterns of urban growth. Urban Geography 2011; 32:406-23.

25. Gobierno del Estado de Baja California. Reglamento de fraccionamientos del Estado de Baja California. Periódico Oficial del Estado de Baja California 1971; Sección I Tomo LVXXVIII(10).

26. Huizar H, Ojeda-Revah L. Los parques de Tijuana: una perspectiva de justicia ambiental. In: Ojeda-Revah L, Espejel I, editors. Cuando las áreas verdes se transforman en paisaje: la visión de Baja California. Tijuana: Colegio de la Frontera Norte; 2014. p. 87-120.

27. Canosa E, Saez E, Sanabria C, Zavala I. Metodología para el estudio de los parques urbanos: la comunidad de Madrid. GeoFocus 2003; 3:160-85

28. Secretaría de Desarrollo Social. Sistema normativo de equipamiento urbano. Tomo V. Recreación y deporte. http://www.inapam.gob. $\mathrm{mx} / \mathrm{es} / \mathrm{SEDESOL} /$ Documentos (accessed on 07/Apr/2016).

29. Craig CL, Marshall AL, Sjostrom M, Bauman AE, Booth ML, Ainsworth BE, et al. International physical activity questionnaire: 12 -country reliability and validity. Med Sci Sports Exerc 2003; 35:1381-95.
30. IPAQ Group. Guidelines for data processing and analysis of the International Physical Activity Questionnaire (IPAQ): short and long forms, 2005. http://www.ipaq.ki.se (accessed on 07/ Apr/2016).

31. Barbosa O, Tratalos JA, Armsworth PR, Davies RG, Fuller RA, Johnson P, et al. Who benefits from access to green space? A case study from Sheffield, UK. Landsc Urban Plan 2007; 83:187-95.

32. Veitch J, Abbott G, Kaczynski AT, Wilhelm SA, Besenyi GM, Lamb KE. Park availability and physical activity, TV time, and overweight and obesity among women: findings from Australia and the United States. Health Place 2016; 38:96-102.

33. Salvo D, Reis RS, Stein AD, Rivera J, Martorell $\mathrm{R}$, Pratt M. Characteristics of the built environment in relation to objectively measured physical activity among Mexican adults, 2011. Prev Chronic Dis 2014; 11:E147.

34. Ekelund U, Sepp H, Brage S, Becker W, Jakes R, Hennings $\mathrm{M}$, et al. Criterion-related validity of the last 7-day, short form of the International Physical Activity Questionnaire in Swedish adults. Public Health Nutr 2006; 9:258-65.

35. Finger JD, Gisle L, Mimilidis H, Santos-Hoevener C, Kruusmaa EK, Matsi A, et al. How well do physical activity questions perform? A European cognitive testing study. Arch Public Health 2015; 73:57. 


\section{Resumen}

El objetivo de este artículo fue investigar la asociación entre el acceso a los espacios públicos y la actividad física en mujeres adultas, controlando $y$ comprobando las interacciones, con características sociodemográficas y espacios públicos. Combinamos información sociodemográfica de una encuesta a mujeres adultas (de 18 a 65 años), residentes en Tijuana, México, que se realizó en 2014 ( $N=$ 2.345); con datos de un estudio sobre espacios públicos en 2013 en la misma ciudad. Evaluamos el acceso a los espacios públicos por su existencia y el área total de espacios públicos en espacios de 400, $800,1.000$ y $1.600 \mathrm{~m}$ alrededor de los hogares de los participantes. Calculamos la actividad física con la versión corta del International Physical Activity Questionnaire (IPAQ-short). Usamos modelos logísticos multinomiales para evaluar la asociación entre el acceso a espacios públicos y actividad física, y comprobar las interacciones entre el acceso a espacios públicos y su calidad, así como las características sociodemográficas de la actividad física. Observamos que no existe interacción entre el acceso a los espacios públicos y la calidad de los espacios públicos y sus efectos sobre la actividad física. Hubo una asociación entre la presencia del espacios públicos dentro de los $400 \mathrm{~m}$ de área, y las probabilidades más altas de contar con un nivel de actividad física bajo (en oposición a estar en el nivel moderado) (coeficiente: 0,50; IC95\%: 0, 13; 0,87). Los participantes que usaron el transporte público estaban en menor medida en el nivel bajo de actividad física (coeficiente: -0,57; IC95\%: -0,97; -0,17). Por este motivo sugerimos que en esta población el acceso a espacios públicos puede ser menos relevante para la actividad física que otros elementos del entorno urbano y características sociodemográficas.

Actividad Física; Áreas Verdes; Salud de la Mujer

\section{Resumo}

$O$ artigo buscou explorar a associação entre o acesso aos espaços públicos e a atividade física em mulheres adultas mexicanas, controlando e testando para interações entre características sociodemográficas e ambientais urbanas. Combinamos dados sociodemográficos de uma pesquisa feita na população feminina adulta (18-65 anos) de Tijuana, México, realizada em $2014(N=2.345)$, e os dados de um estudo (2013) sobre espaços públicos na mesma cidade. Avaliamos o acesso aos espaços públicos pela presença e área total de espaços públicos dentro de raios de 400, 800, 1.000 e 1.600 metros em torno dos domicílios das participantes. Medimos a atividade física com a versão breve do International Physical Activity Questionnaire (IPAQ-short). Foram utilizados modelos logísticos multinomiais para avaliar a associação entre o acesso aos espaços públicos e a atividade física, testando para interações entre acesso aos espaços públicos e qualidade dos espaços públicos e características sociodemográficas. Não constatamos nenhuma interação entre o acesso aos espaços públicos e a qualidade dos espaços públicos, no efeito sobre a atividade física. Houve uma associação entre a presença de espaços públicos no raio de 400 metros e maior probabilidade de estar no nível baixo de atividade física (quando comparado ao nível moderado) (coeficiente: 0,50; IC95\%: 0,13; 0,87). As participantes que usavam transporte público mostraram menor probabilidade de nivel baixo de atividade física (coeficiente: -0,57; IC95\%: -0,97; -0,17). Sugerimos que, nesta população, o acesso aos espaços públicos pode ser menos relevante para $a$ atividade física do que outros elementos do ambiente urbano e características sociodemográficas.

Atividade Física; Áreas Verdes; Saúde da Mulher
Submitted on 14/Apr/2017

Final version resubmitted on 26/Jul/2017

Approved on 07/Aug/2017 